\title{
HSD17B4 wt Allele
}

National Cancer Institute

\section{Source}

National Cancer Institute. HSD17B4 wt Allele. NCI Thesaurus. Code C114365.

Human HSD17B4 wild-type allele is located in the vicinity of 5q21 and is approximately $185 \mathrm{~kb}$ in length. This allele, which encodes peroxisomal multifunctional enzyme type 2 protein, plays a role in the oxidation of fatty acids. Mutation of the gene is associated with D-bifunctional protein deficiency and Perrault syndrome 1. 